\title{
上海市湿地景观格局时空演变与驱动机制的量化研究
}

\author{
易阿岗, 王 钧* \\ 北京大学深圳研究生院城市规划与设计学院, 深圳 518055
}

摘要:基于 1980-2018 年上海市历史遥感数据,定量研究上海市湿地景观格局变化及其驱动机制。为此,采用 Fragstats 4.2.1计 算了景观格局指数,并在数据处理系统软件平台使用灰色关联系统分析了湿地景观格局与社会、经济以及自然环境之间的灰色 关联度。结果表明:(1) 自 1980 以来,上海市湿地面积持续缩减,尤其水田损失最多。截至到 2018 年,上海市共损失了 21.06× $10^{4} \mathrm{hm}^{2}$ 的湿地, 现存湿地面积为 $38.22 \times 10^{4} \mathrm{hm}^{2}$, 其中人工湿地占 $85 \%$, 自然湿地占 $15 \%$ 。人工湿地以水田为主, 自然湿地以河 流湿地为主。水田和河流斑块平均面积总体上呈波动缩小趋势。河流湿地的形状复杂性最高,其总面积在年际间缓慢缩减,平 均分形维度指数年际间波动持平。水田平均分形维度指数年际间波动上升,景观形状向复杂化趋势发展。(2) 1980-2010 年 间,湿地景观破碎化程度总体加剧, 最大斑块指数呈波动下降趋势。2010 年后, 景观破碎化局势向好,最大斑块面积扩大。 1980-2015 年间,曼延度指数呈波动下降趋势,香农多样性指数呈波动上升趋势。2015 年是蔓延度指数和香农多样性指数变 化的转折点。水库坑塘斑块形状较简单,年际间变化小,而且具有结构的自相似性。(3) 湿地景观格局受自然、人为双重因素 影响。城市扩张导致人工湿地面积减少。自然湿地的演变则主要受气温和降雨的影响。自然因素往往在较大的时空尺度上控 制着湿地的景观格局变化。但随着经济的迅速发展,在较短的时间尺度上,国家政策等人为因素对景观格局的影响力逐渐增 强。未来,国家对城市湿地保护政策的实施可以使湿地景观格局向好的方向演化。

关键词 : 湿地; 景观格局; 驱动机制; 灰色关联度; 上海市

\section{Quantitative study on spatio-temporal evolution and mechanisms of wetland landscape patterns in Shanghai}

YI Alan, WANG Jun*

Department of Urban Planning and Design, Shenzhen Graduate School of Peking University, Shenzhen 518055, China

\begin{abstract}
Based on historical remotely sensed data covering the city of Shanghai between 1980 and 2018, we conducted quantitative studies on wetland landscape change and its driving mechanisms. In order to do so, we calculated landscape pattern indices by Fragstats 4.2.1 and analyzed the grey correlations between wetland landscape patterns and social, economic, and natural environments using grey relational analysis in data processing systems. The results showed that (1) the total area of wetlands, especially paddy fields, have been decreasing since the year 1980. By the year 2018, the wetland area has been reduced by $21.06 \times 10^{4} \mathrm{hm}^{2}$. The total area of wetland in Shanghai was $38.22 \times 10^{4} \mathrm{hm}^{2}$, and $85 \%$ of the area was the constructed wetland, the rest was the natural wetland. Constructed wetlands were mainly comprised by paddy fields, while natural wetlands were mainly river wetlands. The average areas of paddy fields and river patches showed fluctuated decreasing trends. The shape of river wetland patches was the most complex, and the total area of the river patches had been
\end{abstract}

基金项目:国家科技计划项目（2017YFC0505801）；深圳市科技计划基础研究项目 (JCYJ20180302150417674); 国家自然科学基金面上项目 (41871191)

收稿日期: 2020-02-15; 网络出版日期:2021-01- 27

*通讯作者 Corresponding author.E-mail: wangjun@ pkusz.edu.cn 
decreasing over the study period. The fractional dimensions index of the river patches fluctuated over the years but did not have a clear trend. The fractional dimension index of paddy fields fluctuated and had an increasing trend, and their landscape patterns had become more complex. (2) The degree of fragmentation of wetland landscapes intensified between 1980 and 2010, and the maximum patch index showed a fluctuated decreasing trend. Around the year 2010, the degree of fragmentation of wetland landscapes reversed, and the maximum patch index had become increasing. Between 1980 and 2015, the contagion index showed a fluctuated decreasing trend and the Shannon diversity index showed a fluctuated increasing trend. The year 2015 was the tipping point for the changes of the contagion index and the Shannon diversity index. The patch shape of reservoirs was relatively simple, and they had small inter-annual fluctuations and structural selfsimilarity. (3) The landscape patterns of wetlands were influenced by natural and human disturbances. Urbanization caused the decrease of constructed wetlands. The change of natural wetlands was mainly driven by the variations of temperature and precipitation. Natural factors usually had dominant influence on wetland landscape in large spatial and temporal scales. In the context of rapid economic development, human factors, such as national policy, had increasingly stronger influence on wetland landscape patterns in short temporal scale. In the future, the implementation of national policies on urban wetland conservation can help urban landscape patterns move toward better directions.

Key Words : wetland; landscape pattern; mechanism; gray correlation degree; Shanghai City

湿地是公认的自然界中生产力最高的生态系统 ${ }^{[1]}$,直接或间接地影响着人类的福祉,包括农产品生产、 水质调节、气候调节、水文循环、生物地球化学循环、风暴防护和提供物种栖息地等 ${ }^{[2-5]}$ 。当前,全球湿地退化 形势严峻,尤其亚洲地区的湿地损失最多 ${ }^{[6]}$ 。上海作为中国经济最发达的地区,其湿地面积在改革开放之后 因经济的发展和城市化而迅速缩减 ${ }^{[7]}$ 。

近年来,关于湿地遥感影像解译、湿地面积和类型的变化以及湿地退化因素方面的研究数量日益增 加 ${ }^{[6-7]}$, 使用多时期遥感影像分析湿地时空演变已成为主流 ${ }^{[8-9]}$ 。同时, 湿地景观格局演变以及驱动机制也开 始引起人们的关注 ${ }^{[8-10]}$ 。上海市湿地资源丰富, 其中崇明岛东滩湿地是众多候鸟迁徙路线的中转站 ${ }^{[11]}$ 。前 人研究显示湿地中物种丰富, 如: 鸟类会优先使用湿地作为栖息地, 因此湿地景观格局的变化直接影响到物种 的多样性 ${ }^{[12-13]}$ 。伴随着上海市经济高速发展, 城市化不断推进以及人类活动日益增多, 湿地已成为研究的热 点, 主要研究方向包括湿地面积和类型的变化 ${ }^{[7]}$, 沿海湿地景观格局的变化 ${ }^{[8]}$, 沿海土地开圼 ${ }^{[14]}$, 海平面上升 对湿地的影响 ${ }^{[15-16]}$, 以及湿地底栖动物和微生物的变化等 ${ }^{[13,17]}$ 。湿地景观面临着巨大的退化及破碎化压力, 这给上海市生态环境安全带来潜在威胁。在这样的背景下, 掌握湿地景观格局变化的规律显得尤为重要。然 而, 很少有人研究上海市湿地景观时空格局演变以及量化其驱动机制。虽有已有对长江口湿地的景观格局驱 动机制的研究, 但仅局限于社会经济因素, 未能将自然因素纳人其中 ${ }^{[8]}$ 。景观格局对生态安全的影响随区域 和空间规模的不同而有很大差异 ${ }^{[18]}$ 。分析上海市关键景观格局指数可以揭示湿地景观动态变化特征及其分 布规律, 对湿地资源管理和可持续发展等方面具有重要意义。研究可为监测和规划上海市湿地资源, 优化景 观格局和保护上海市湿地环境提供科学依据。为此,本文旨在: (1) 基于多时期遥感影像数据, 利用 ArcGIS 软 件、Fragstats 软件分析上海市 1980-2018 年的湿地景观格局时空演变趋势; (2) 利用数据处理系统软件( Data Processing System, DPS), 通过分析社会、经济以及自然指标与湿地景观指标之间的相关性, 定量研究社会、经 济以及自然因素对上海市湿地景观格局演变的影响; (3) 找出影响上海市湿地景观格局演变的主要驱动力。

\section{1 方法}

\section{1 研究区概况}

上海市地处中国大陆东部, 长江口沿岸, 河流、湖泊众多。陆域面积 $6.83 \times 10^{5} \mathrm{hm}^{2}$ 。它是中国人口最稠密 的地方之一。除西南部有少数丘陵山脉外, 其他土地都为平坦的冲积平原, 平均海拔约 $2.19 \mathrm{~m}$ 。年平均降雨 
量为 $1457.90 \mathrm{~mm}$, 年平均气温为 $17.80^{\circ} \mathrm{C}$, 雨季多发生在 5-9 月。独特的地理位置和气候使得其拥有丰富的 湿地资源。虽然水资源相对丰富, 但人均水资源紧张, 主要依赖于其他地区水资源 ${ }^{[19]}$ 。湿地水资源可以用作 农业、畜牧业、渔业和生活用水的来源 ${ }^{[20]}$ 。而湿地资源的丧失加剧了上海市资源性缺水、生态功能下降。鉴 于上海是中国四大直辖市之一、是国家历史文化名城、是国际经济、金融、贸易、航运以及科技创新中心, 科学 的湿地保护、规划和开发可以为其带来巨大的生态、经济和社会效益。

\section{2 遥感数据的选取与处理}

本研究中的土地利用/覆盖数据主要采用监督分类方法结合目视解译分别从 Landsat-MSS 遥感影像 (1980 年)、Landsat TM/ETM 遥感影像(1990 和 2000 年)、Landsat-TM 遥感影像( 1995、2005 以及 2010 年)、 Landsat 8 遥感影像 (2015 和 2018 年) 获取。遥感影像无云, 空间分辨率为 $30 \mathrm{~m}$ 。在 ENVI 5.3 和 ArcGIS 10.2 软件中进行辐射定标和波段融合。采用 Kappa 系数检验方法对其进行精度检验,结果显示, 各时期的遥感影 像 Kappa 系数均高于 0.80 , 满足本研究需求。依据中国滨海湿地分类方案并结合上海市湿地特征将湿地分为 自然湿地 (含河流、湖泊和滩涂) 和人工湿地 (含水库坑塘和水田) (图 1)。
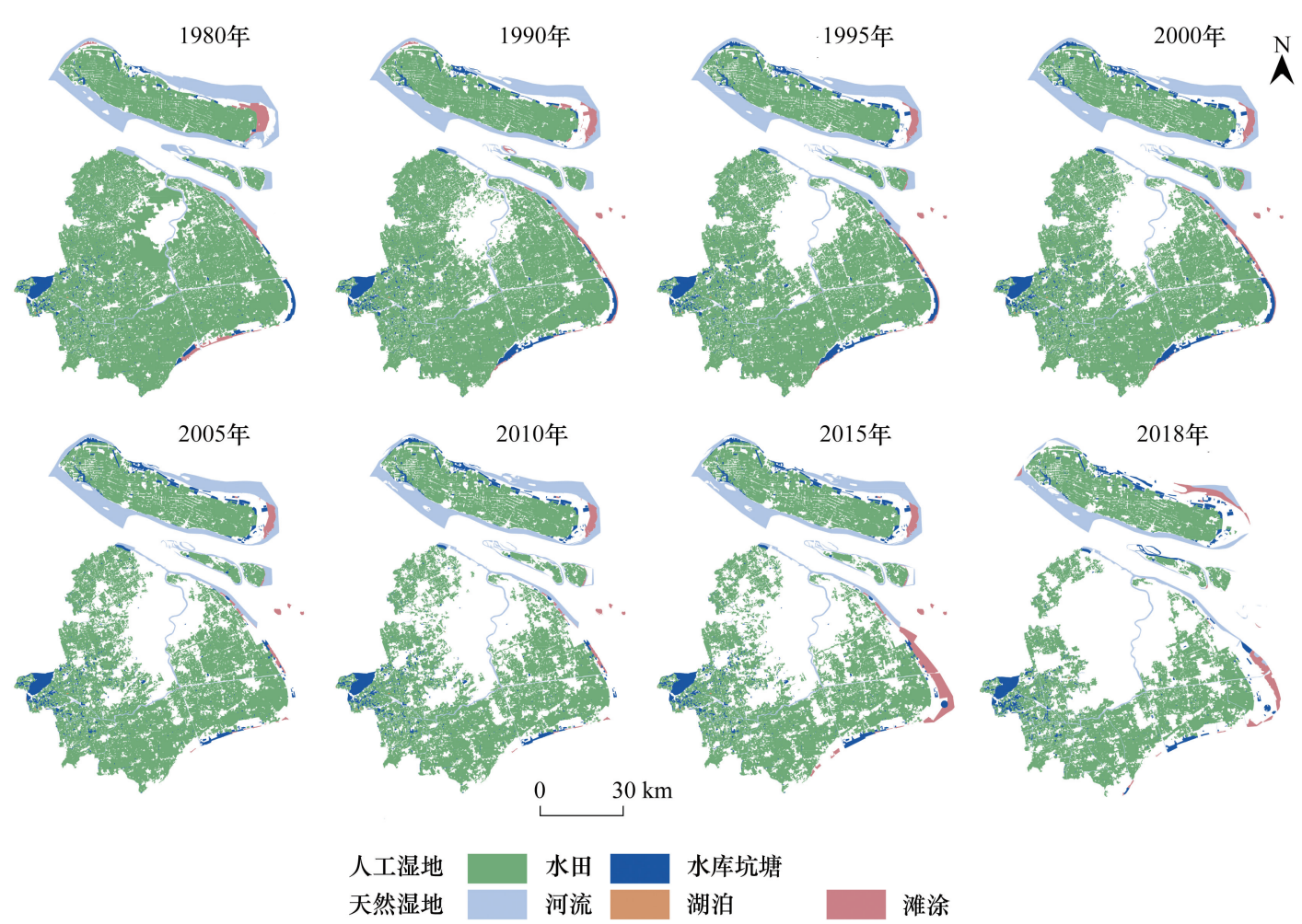

2015年

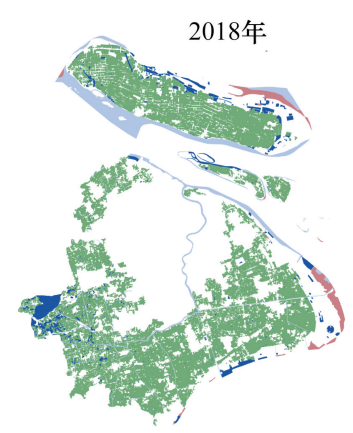

图 1 上海市湿地时空分布图(1980-2018 年)

Fig.1 Spatio-temporal distribution of wetlands in Shanghai (1980-2018)

1.3 湿地景观格局指标的选取与计算

景观格局指数是对空间景观格局的高度概括, 能有效反映景观的构成和空间结构 ${ }^{[10]}$ 。生态安全与景观 格局指数联系紧密, 景观斑块的大小、斑块的形状、斑块的类型以及景观的空间格局对生态安全都具有重要影 响 ${ }^{[18]}$ 。但是, 各种景观指标之间具有一定的关联, 使用较少的指标来表征城市景观格局已成为趋势 ${ }^{[8,21-22]}$, 结 合上海市湿地特点, 从斑块、类型和景观 3 个尺度共选取了 8 个景观指标,包含斑块类型面积、斑块平均面积、 平均分形维数分布、景观面积、最大斑块指数、景观形状指数、蔓延度以及香农多样性指数,每个指标所表达的 生态学意义见表 1 。 
表 1 选取的景观指标及其生态学意义

Table 1 Selected landscape Indices and their ecological meanings

\begin{tabular}{|c|c|c|}
\hline 指标 Indices & 尺度 Scale & 生态学意义 Ecological meanings \\
\hline 类型面积 Class area & 类型 & 度量景观的组分, 是计算其他指标的基础 \\
\hline $\begin{array}{l}\text { 斑块平均面积 } \\
\text { Mean patch area distribution }\end{array}$ & 类型 & $\begin{array}{l}\text { 斑块平均面积的分布区间对图像或地图的范围以及对景观中最小斑块粒径的选 } \\
\text { 取有制约作用; 另一方面斑块平均面积可以指征景观的破碎程度 }\end{array}$ \\
\hline $\begin{array}{l}\text { 平均分形维数分 } \\
\text { Mean fractal index distribution }\end{array}$ & 类型 & 体现斑块类型的形状复杂程度, 其值介于 $1-2$, 数值越大, 形状越迁回曲折 \\
\hline 景观面积 Total area & 景观 & 决定景观的范围以及研究和分析的最大尺度, 是计算其他指标的基础 \\
\hline $\begin{array}{l}\text { 景观形状指数 } \\
\text { Landscape shape index }\end{array}$ & 景观 & $\begin{array}{l}\text { 当景观形状为圆形或者正方形时, 其数值最小为 } 1 \text {, 斑块的形状越复杂或者越扁 } \\
\text { 景观形状指数就越大 }\end{array}$ \\
\hline $\begin{array}{l}\text { 最大斑块指数 } \\
\text { Largest patch index Total area }\end{array}$ & 景观 & 在景观尺度上等于景观中最大斑块的面积占总景观面积的百分比 \\
\hline $\begin{array}{l}\text { 蔓延度 } \\
\text { Contagion index }\end{array}$ & 景观 & $\begin{array}{l}\text { 描述景观中不同斑块类型的延展趋势或团聚程度。数值大代表景观由少数团聚 } \\
\text { 的大斑块组成,取值小则代表景观由许多小斑块组成 }\end{array}$ \\
\hline $\begin{array}{l}\text { 香农多样性指数 } \\
\text { Shannon's diversity index }\end{array}$ & 景观 & $\begin{array}{l}\text { 反映景观异质性,对景观中各斑块类型非均衡分布状况较为敏感。值越高, 说明 } \\
\text { 土地利用越丰富,破碎化程度越高,不定性信息含量越大 }\end{array}$ \\
\hline
\end{tabular}

Fragstats 4.2.1 是景观格局分析的一种软件,可量化景观格局的时空特征, 目前可计算 100 余种景观指数。 在 ArcGIS 10.2 中将矢量图层转出为 $30 \mathrm{~m} \times 30 \mathrm{~m}$ 精度的栅格图层。再利用 Fragstats 4.2.1 计算湿地景观格局 指数,将计算出的结果采用 Origin 2019b 软件绘制出图,提高结果的可视化。

1.4 社会、经济以及自然指标的选取与计算

上海市湿地格局变化受到人为和自然的影响,如经济增长、水利工程、地形、降水、气候变化、长江上游的 来水量和输沙量以及水产养殖等 ${ }^{[6,9,23]}$ 。此外, 湿地的变化往往与城市的扩张相关, 城市的扩张与国内生产总 值 (GDP) 、人口以及城市化水平密切相关 ${ }^{[7]}$ 。由于上海市除了西南地区有较少山脉之外, 其余多为冲击平 原, 故本文忽略地形对于湿地的影响 ${ }^{[6]}$ 。长江流域上海段水下地形复杂, 数据难以获取, 故本文的研究区范 围不包含长江流域上海段的河口湿地。综上,本文从社会、经济以及自然三大方面共选取 21 个与上海市湿地 景观格局演变最相关的指标, 量化社会、经济以及自然对湿地景观格局的影响。其中,社会因素方面选取港口 货运吞吐量、市政道路面积、常住人口、城镇人口比重、农作物播种面积、房屋施工面积、水产养殖产量、沿海码 头长度以及沿海泊位, 共 9 个指标; 经济因素方面选取住宅投资、房地产开发投资、城市基础设施投资、第一产 业产值、第二产业产值、第三产业产值、种植业产值以及渔业产值, 共 8 个指标; 自然因素方面选取年平均气 温、年平均降雨量、长江年输沙量以及长江年径流量, 共 4 个指标。社会因素、经济因素以及部分自然因素 (平均气温、降雨量) 方面的指标数据来源于《上海年鉴》(1981、1984、1991、1996、2001、2006、2011、2016 以及 2019 年)、《中国统计年鉴》(2001、2006、2011、2016 以及 2019) 以及《新中国六十年统计资料汇编》; 长江年输 沙量和长江年径流量数据采用最靠近上海市的大通监测站数据, 来源于《中国河流泥沙公报》(2002、2005、 $2010 、 2015$ 以及 2018 年)。2000 年及以前的数据采用《中国河流泥沙公报》推荐的多年平均值代替。考虑到 1980 年距现在年代久远, 故采用国家统计局提供的全国零售物价总指数将 2018 年以前的价值指标 (包括房 地产开发投资、城市基础设施投资、第一产业产值、第二产业产值、第三产业产值、种植业产值、渔业产值以及 住宅投资) 数据换算成以 2018 年为标准的数值, 便于比较不同时期的价值以及剔除价格变化的影响, 从而能 精准反映物量变化和生产活动成果的实际变动。

1.5 湿地景观格局指标与社会、经济以及自然指标的灰色关联度计算

DPS 软件研发于 1988 年, 是目前在技术上已达到国际先进水平的多功能统计分析软件, 其中的灰色系统 可以应用于关联分析、预测模型以及综合评价 ${ }^{[24]}$ 。灰色关联度分析的原理是基于行为因子之间的宏观或微 观几何近似,阵列曲线越相似,因子之间的联系越紧密 ${ }^{[25]}$ 。多用于衡量主行为因子与行为因子之间的密切程 度, 可根据关联度大小确定主要因素和次要因素, 在分析部分信息已知, 部分信息未知的系统时具有重要优 
势 ${ }^{[26-27]}$ 。本文利用 DPS 7.05 软件平台计算分析社会、经济以及自然方面的 21 个主要指标和 12 个湿地景观 指标之间的灰色关联度。所选取的 12 个湿地景观指标分别是水库坑塘面积、水田面积、滩涂面积、湖泊面积、 河流面积、人工湿地、自然湿地、湿地总面积、景观形状指数、最大斑块指数、蔓延度指数以及香农多样性指数。

\section{2 结果分析}

2.1 湿地面积及形状变化趋势分析

1980-2018 年间,上海湿地总面积不断下降,截至 2018 年,上海市湿地面积仅存 $38.22 \times 10^{4} \mathrm{hm}^{2}$,近 40 年 间,湿地面积损失超过 60\% (1980 年为 59.28 $\times 10^{4} \mathrm{hm}^{2}$ ), 尤其在 2015-2018 年间,湿地总面积损失速率最大。 在研究时段内, 上海市湿地构成以人工湿地为主,占湿地总面积的 $80 \%$ 以上,其年际间面积变动较大,而自然 湿地面积年际间基本持平 (图 2)。在人工湿地中水田面积占比以及年际间面积变动均为最大(1980-2018 年间,水田面积缩减了 39\%)。自然湿地以河流湿地为主,其面积在年际间缓慢缩减。2005 年以前, 河流、水 库坑塘、滩涂以及湖泊的面积年际间基本持平,但在 2005-2018 年间,除水库坑塘外,其他类型湿地面积变化 显著,湖泊面积呈扩大趋势, 河流面积呈缩减趋势, 滩涂面积呈波动状态 (图 2)。
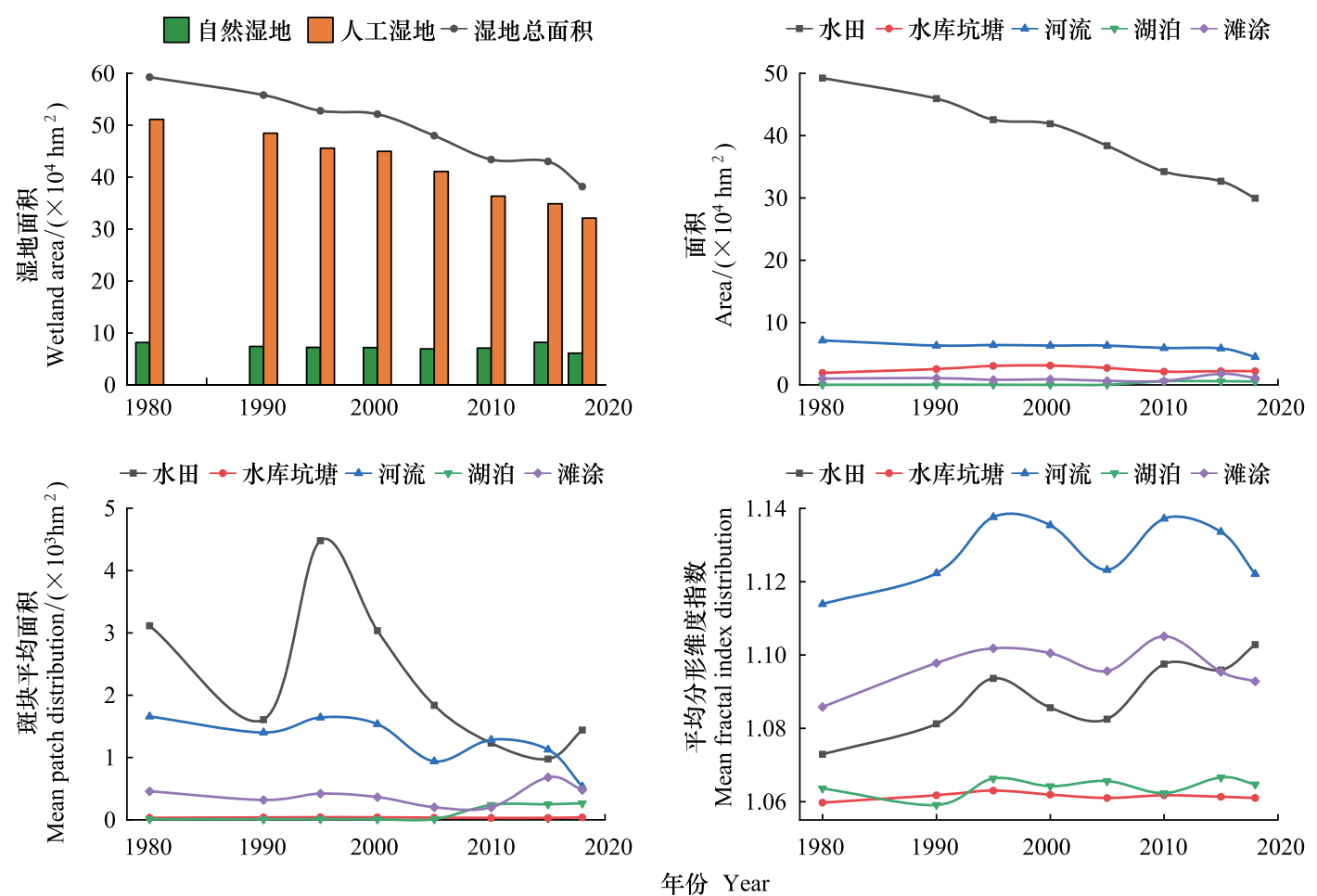

图 2 上海市湿地的总面积、各类湿地面积、斑块平均面积以及平均分形维度年际变化图 (1980-2018 年)

Fig.2 Interannual changes of total area, area of various types, mean patch area distribution and mean fractal index distribution of wetlands in Shanghai $(1980-2018)$

斑块平均面积可以定量描述湿地景观破碎化程度。水田斑块平均面积最大, 同时其也是年际间波动幅度 最大的湿地类型;其次是河流斑块平均面积,但年际间不稳定,总体上呈退化趋势; 水库坑塘斑块平均面积较 小,年际间较稳定(图 2)。

平均分形维度指数分布可以描述湿地斑块形状的复杂程度,数值越大代表景观愈复杂或呈扁长形态。河 流的平均分形维度指数分布最高是由于河流本身的性质决定它是细长形态,其数值在 1.13 附近波动。水库 坑塘的景观形状较简单, 年际间变化小, 且在类型尺度范围中具有结构的自相似性。水田的平均分形维度指 数呈波动上升态势 (图 2)。 
景观形状指数主要体现景观要素边界特征。在 2010 年前,上海市湿地景观形状指数逐年上升,表明湿地 斑块与基质的交互作用增大, 斑块形状愈发复杂, 可能导致上海市的湿地景观退化并出现较多的生态效应; 在 2010 年后, 景观形状指数开始下降 ( 图 3)。

最大斑块指数表征某一类型的最大斑块在整个景观中所占比例。最大斑块指数从 1980 年以来总体呈下 降趋势, 直到 2010 年后才出现回转, 这表明上海市需要继续加强湿地管理, 提升最大斑块指数, 确保湿地动植 物的生境不受威胁 (图 3)。

2.2 湿地结构组成变化分析

蔓延度指数体现了景观中各斑块类型的团聚程度或延展态势, 其取值范围在 $0-100$,值越小表明景观存 在越多小斑块, 反之则说明景观中有连通度较高的优势斑块类型。1980-2018 年间, 上海市湿地景观蔓延度 指数均在 74 以上, 总体呈现先下降后上升的趋势, 2015 年是主要转择点 (图 4)。香农多样性指数反映景观异 质性, 可以展示湿地景观中各斑块类型非均衡分布情况。上海市湿地景观的香农多样性指数从 1980 年的 0.59 增加到 2015 年的 0.82 , 之后急剧下降 (图 4), 这表明在 2015 年以前各类型湿地斑块增加或各斑块类型在 景观中呈均衡化趋势发展, 直到 2015 年后, 这种局势才得以反转。

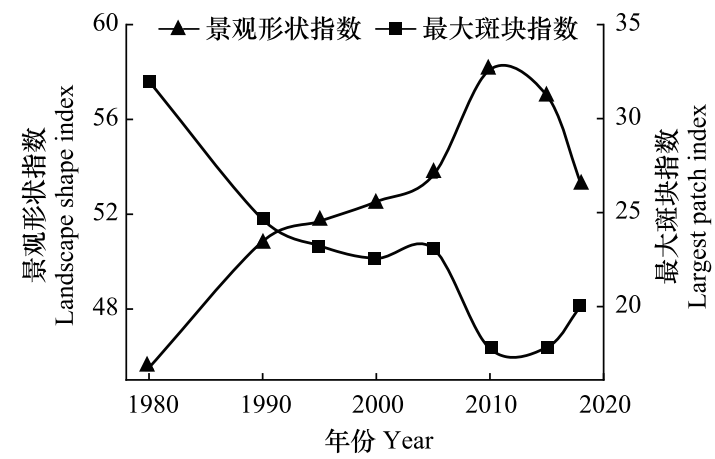

图 3 上海市湿地景观形状指数与最大斑块指数年际变化图 (1980-2018 年)

Fig.3 Interannual changes of landscape shape index and largest patch index in Shanghai (1980-2018)

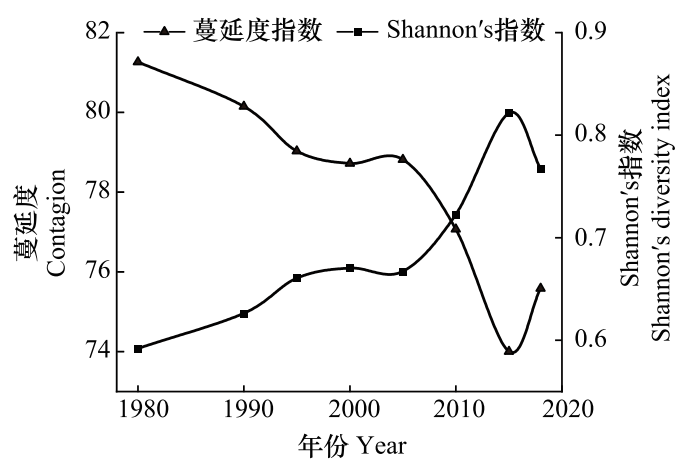

图 4 上海市湿地蔓延度指数与香农多样性指数年际变化图 (1980-2018 年)

Fig.4 Interannual changes of Contagion index and Shannon's diversity index in Shanghai $(1980-2018)$

\section{3 社会、经济以及自然指标与湿地景观格局指标的灰色关联度分析}

\subsection{1 社会指标与湿地景观格局指标的关联度分析}

在所选取的 9 个社会因素中 (包含港口货运吞吐量、市政道路面积、常住人口、城镇人口比重、农作物播 种面积、房屋施工面积、水产养殖产量、沿海码头长度以及沿海泊位), 与 12 个湿地景观格局指标的关联度在 0.15-0.71 之间, 平均关联度为 0.39 (图 5)。农作物播种总面积与湿地总面积, 人工湿地以及水田面积的灰 色关联度分别为 $0.68 、 0.71$ 以及 0.71 , 即湿地总面积、人工湿地以及水田面积与农作物播种总面积关系密切。 从社会因子对所有湿地景观格局指标的平均关联度看,农作物总播种面积、常住人口以及水产养殖产量与湿 地景观格局的关联较强,而市政道路的建设与湿地景观格局的关联较弱。

\subsection{2 经济指标与湿地景观格局指标的关联度分析}

选取的 8 个经济因子与湿地景观格局指数的关联度分布在 $0.20-0.61$ 范围内, 平均关联度为 0.34 (图 5)。经济产值的大小可以侧面反映出土地类型的变化 ${ }^{[28]}$ 。在所有经济指标中,第三产业产值与湖泊面 积的关联最强 (灰色关联度为 0.49 ), 即在本研究范围内,第三产业的发展是影响湖泊面积的最重要的因素。 综合所有经济因子对湿地景观格局指标关联度的平均值看, 与湿地景观格局关系最密切的是第一产业产值 (平均关联度为 0.48 ), 说明在经济因素范围内, 第一产业的发展对湿地景观格局的影响较大。此外, 在所有 经济因素中,第一产业产值与香农多样性指数的关联度最大 (为 0.61 ), 说明第一产业的发展是湿地斑块类型 


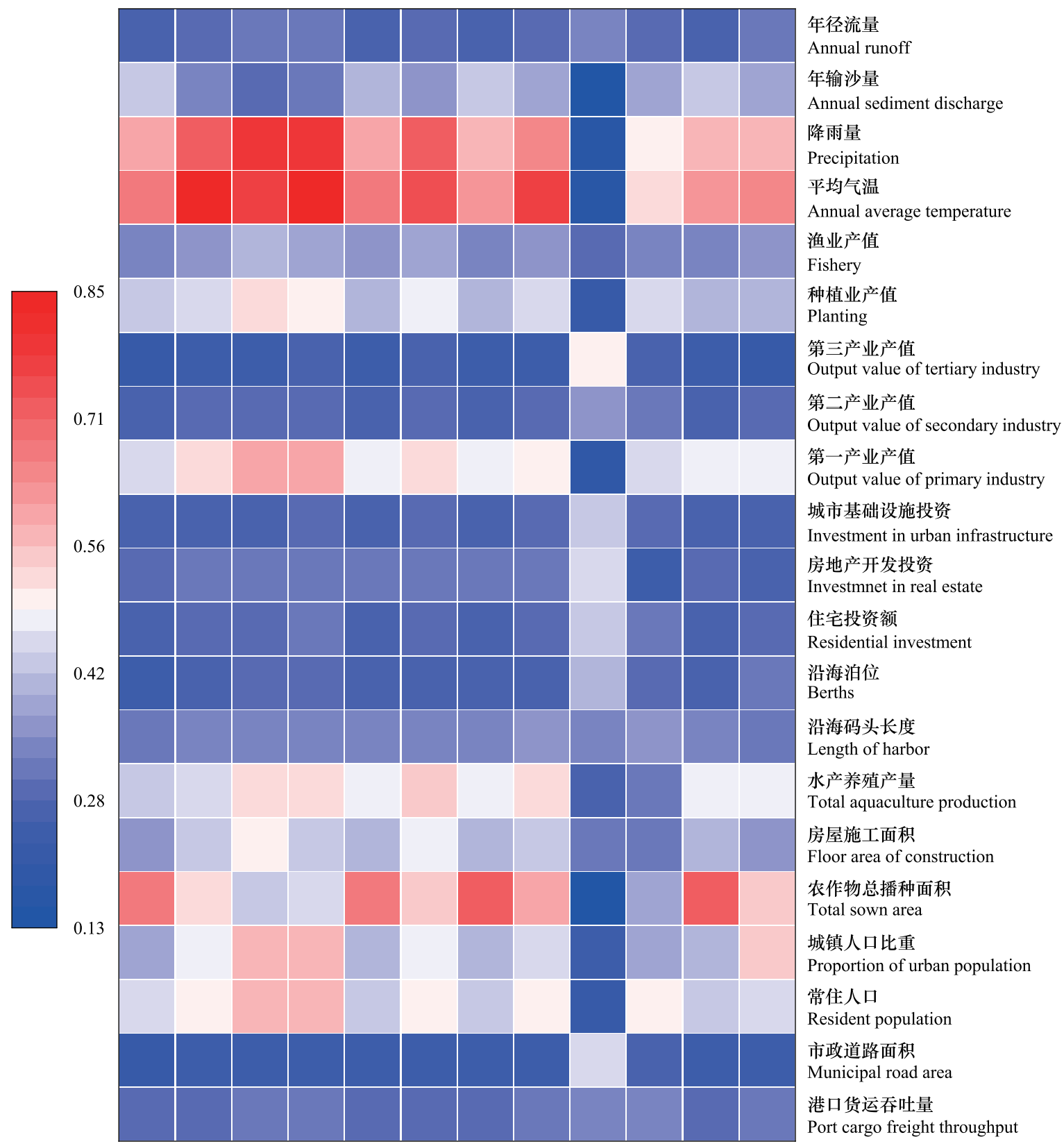

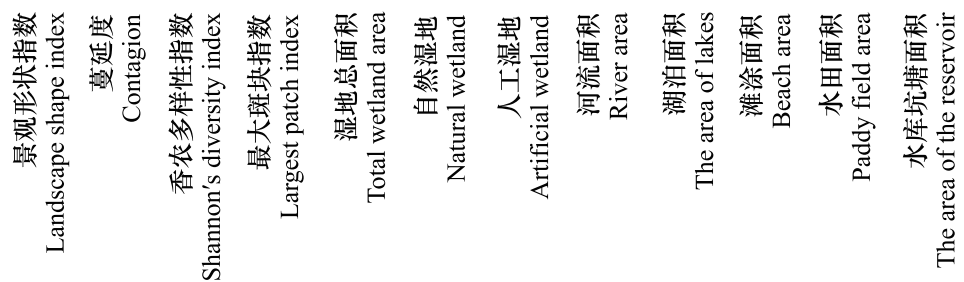

图 5 社会、经济以及自然指标与湿地景观格局指标的灰色关联度

Fig.5 Gray correlation degree of indicators between social, economic, natural indices and wetland landscape patterns

呈均衡化分布的驱动因素之一。

\subsection{3 自然指标与湿地景观格局指标的关联度分析}

选取的 4 个自然因子与湿地景观格局指数的关联度在 $0.14-0.85$ 范围内, 平均关联度为 0.48 (图 5)。所 有社会、经济以及自然指标中, 平均气温对景观形状指数、蔓延度以及最大斑块指数的影响最大。此外, 平均 
气温对自然湿地面积、河流面积、滩涂面积以及水库坑塘面积也具有一定的影响。香农多样性指数与降雨量 的关联度最大。综合来看,平均气温、降雨量是影响湿地景观格局最主要的两个因素。

综合社会、经济以及自然因素,在影响湿地景观格局的 21 个因素中,湿地总面积主要受农作物播种总面 积、平均气温以及降雨量的影响。人工湿地面积主要受农作物播种总面积、平均气温的影响。自然湿地面积 主要受平均气温和降雨量的影响。景观形状指数、蔓延度以及最大斑块指数主要受平均气温的影响。香农多 样性指数与降雨量的变化最相关。

2.4 湿地景观演变驱动机制分析

2.4.1 自然因素

气候变化主要包括气温变化和降水变化两方面。 1980 - 2018 年, 上海市年平均气温从 $15.70^{\circ} \mathrm{C}$ 上升 $17.75^{\circ} \mathrm{C}$, 年降雨量从 $1123.40 \mathrm{~mm}$ 上升到 $1308.40 \mathrm{~mm}$ (图 6)。自然湿地面积与平均气温以及降雨量的关联 度分别为 $0.75 、 0.71$, 可见气温和降雨量是导致自然湿 地面积退化的重要驱动因子。气温的升高加速了地面 的蒸腾, 从而造成湿地缺水退化, 尤其是自然湿地的退 化。上海市降雨量十年间波动上升, 虽然降雨能为湿地 提供水源补给,增加水面面积,恢复部分湿地,但自然湿 地仍然不断退化。长江每年携带大量的泥沙流向东中 国海, 当河流汇人大海时, 潮汐将沉积物沿着上海海岸

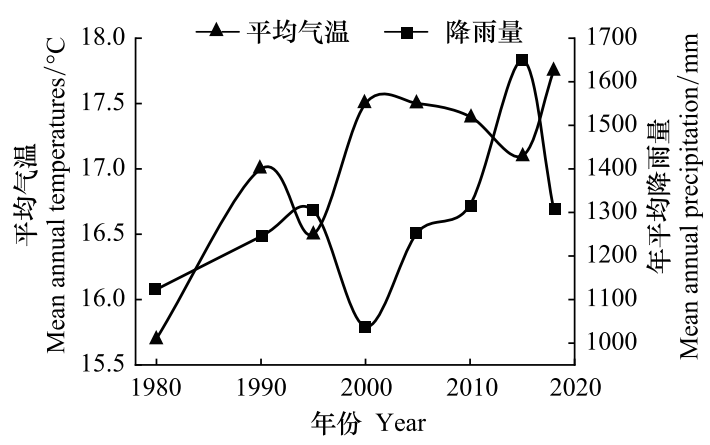

图 6 上海市平均气温和降雨量年际变化图 (1980-2018 年)

Fig.6 Interannual changes of mean temperatures and precipitation in Shanghai $(1980-2018)$

线向南移动导致浦东新区南汇角一直在扩大 ${ }^{[29]}$ 。从关联度看 (图 5), 长江的年输沙量、年径流量对整个自然 湿地面积的影响相对较小。在社会因素中,水产养殖产量、农作物播种总面积、常住人口与自然湿地面积的关 联度分别为 $0.54 、 0.54 、 0.51$ 。综上, 可认为, 在自然湿地退化中, 气候因素占据主导。

\subsection{2 人为因素}

1980-2018 年,上海市农作物播种总面积持续缩减。截至 2018 年底, 上海市湿地以人工湿地为主,占所 有湿地的 $85 \%$ 以上。人工湿地与农作物播种总面积的关联度高达 0.71 , 水田面积与农作物播种总面积的关 联度为 0.71 (图 5)。城市的扩张占用了大量的水田, 水田变成了工业用地、居住用地等 ${ }^{[30]}$, 这直接影响到农 作物播种总面积减少。水田是上海市人工湿地中的主要类型, 表明城市扩张才是造成人工湿地退化最主要的 因素。此外,人工湿地与平均气温和降雨量的关联度分别为 0.64 和 0.58 , 说明平均气温与降雨量的变化对人 工湿地的退化也具有一定的贡献。

\subsection{3 国家宏观政策因素}

湿地景观格局变化受多种因素共同影响 (图 5)。在所有影响景观形状指数、蔓延度指数、香农多样性指 数以及最大斑块指数的因素中, 平均气温和降雨量与这四个景观格局指数的关联最紧密。上海市大部分属于 平原,湿地水面面积容易受到气温和降雨量的影响。当气候干暖时,湿地会出现退化,致使各湿地斑块间的连 通性降低, 而暖湿的气候环境则有利于湿地的恢复与发育 ${ }^{[31]}$ 。在 2015-2018 年间,气候朝暖干化趋势发展 (图 6), 但上海市湿地景观格局趋势向好, 景观形状指数和香农多样性指数下降, 最大斑块指数和蔓延度指数 上升。由此可见,湿地景观局势变好还受到其他因素的干扰,有研究表明国家政策对土地利用/覆盖类型具有 较强的影响力 ${ }^{[14]}$ 。2010 年,上海市规划和自然资源局提出要注重水田保护;2015 年, 中央 1 号文件明确强调 了耕地保护工作,并提出永久基本农田划定、实施高标准农田建设规划等; 上海市规划和自然资源局也进一步 完善了耕地保护和耕地占补平衡政策, 优化土地使用结构,同年,也印发了《关于进一步加强本市河道规划管 理的若干意见》,要求严控水面率,保护河道、湖泊、人工水道等; 2016 年,上海市政府印发《上海市环境保护和 生态建设 “十三五”规划》,指出要注重水田保护和修复。伴随着国家保护政策的落实,在 2015 后期, 上海市 
的河流、滩涂、湖泊以及水库坑塘的斑块形状趋于简单化,但水田的斑块形状仍然朝复杂化趋势发展 (图 2)。 综上,自然因素往往在较大的时空尺度上控制着湿地的景观格局变化,但随着经济的迅速发展,在较短的时间 尺度上,国家政策、人类活动对景观格局的影响力逐渐增强。

\section{3 讨论}

\section{1 数据选取}

以往关于上海市景观格局时空演变的相关研究中多基于 2015 年前的 3-5 期遥感影像数据进行分析,难 以为湿地管理提供最新参考, 且数据的时间跨度较短不足以全面评估湿地景观格局变化。上海市正处于经济 社会高速发展期, 景观格局的年际间变化速率显著加快, 且当今全球气候多变,需要加强湿地的管理与监测, 确保湿地生态安全。本文从 1980-2018 选取 8 期遥感数据对上海市湿地景观格局进行分析, 有效地弥补了 以往数据年代久远的不足, 更好地反映了上海市近 40 年来湿地景观格局的变化特征。《拉姆萨尔公约》提出 的湿地定义包括“低潮时水深不超过 $6 \mathrm{~m}$ 的区域 ${ }^{[32]}$, 长江口水下地形复杂, 难以提取湿地区域, 故本文中在选 取研究对象时,未将长江水域纳人研究范围。

\section{2 驱动机制分析}

以往研究景观格局演变的驱动机制多停留着在定性分析层面,难以为解决实际问题提供科学参考依据。 虽有部分研究者为量化景观格局演变驱动机制而采用 Pearson 相关系数分析, 但是仅基于 5-10 期的遥感样 本数据难以给出有效的具有统计学意义的结果。灰色关联度分析法是将研究对象及影响因子的值视为一条 线上的点, 比较研究对象的曲线与影响因子的曲线之间的贴合程度,计算出研究对象与影响因子之间的关联 度,关联度的大小则代表影响因子对研究对象的影响程度。影响湿地景观格局的因子众多,各因子之间的关 系密切, 由于自然因素和人为因素的复杂以及人们认知水平的限制, 多种因素之间的关系是灰色的, 难以用统 计方法分析各因子间的主次关系。且目前影响湿地景观格局的因子的数据难以全部获取,而灰色关联度分析 法则非常适用于评估这种部分信息已知, 部分信息未知的系统 ${ }^{[24]}$ 。本文研究采用灰色关联度分析法量化并 比较了每种驱动因子的贡献。但这种方法并不能判断正负相关性。21 个指标所代表的含义并不能直接作为 影响湿地景观格局的因素, 需要根据前人的研究经验, 人为判断社会、经济以及自然指标与现实驱动因子的关 系。在本文研究研究中, 虽然自然因素在大背景下影响着湿地景观格局,但国家的宏观政策也是不可忽视的。 所以在驱动机制的分析中,加人国家政策的分析就显得尤为重要。国家政策难以量化, 只能根据实际情况结 合经验加以说明其对湿地景观格局的影响。在今后的研究中, 将进一步探讨政策因子对于湿地景观格局的作 用过程。

\section{4 结论}

本文基于 1980-2018 年上海市遥感影像数据, 选取典型景观格局指标, 以上海市湿地景观为研究对象, 利用 Fragstats 4.2.1 软件计算湿地景观格局指标, 使用 DPS 7.05 软件量化湿地景观格局指标与社会, 经济以 及自然因素之间的灰色关联度, 探讨 1980-2018 年上海市湿地景观格局演变趋势及其驱动机制。结果表明:

1) 截至 2018 年, 上海市湿地面积为 $38.22 \times 10^{4} \mathrm{hm}^{2}$, 其中人工湿地占 $85 \%$, 自然湿地占 $15 \%$ 。人工湿地以 水田为主, 自然湿地以河流湿地为主。湿地面积自 1980 年以来持续缩减,尤其水田损失最多,水田和河流斑 块平均面积总体上呈波动缩小趋势。河流湿地的形状复杂性最高, 其总面积在年际间缓慢缩减, 平均分形维 度指数年际间波动性持平。水田平均分形维度指数年际间波动上升, 景观形状向复杂化趋势发展。

2) 1980-2010 年间,湿地景观破碎化程度总体加剧,最大斑块指数呈波动下降趋势, 2010 年后,景观破碎 化局势向好,最大斑块面积扩大。1980-2015 年间,曼延度指数呈波动下降趋势, 香农多样性指数呈波动上 升趋势, 2015 年是蔓延度指数和香农多样性指数变化的转折点。水库坑塘的景观形状较简单, 年际间变化 小,且在类型尺度范围中具有结构的自相似性。 
3)湿地景观格局受自然、人为双重因素影响。人工湿地退化主要由于城市扩张所导致的水田面积减少， 自然湿地的演变则主要受气温和降雨的影响。自然因素往往在较大的时空尺度上控制着湿地的景观格局变 化,但随着经济的迅速发展,在较短的时间尺度上,国家政策与人类活动对景观格局的影响力逐渐增强。未 来,国家对城市湿地保护政策的实施可以使湿地景观格局向好的方向演化。

\section{参考文献 (References) :}

[ 1 ] Wondie A. Ecological conditions and ecosystem services of wetlands in the Lake Tana Area, Ethiopia. Ecohydrology \& Hydrobiology, 2018, 18 (2) : 231-244.

[ 2 ] Barbier E B. Valuing the storm protection service of estuarine and coastal ecosystems. Ecosystem Services, 2015, 11: 32-38.

[ 3 ] Wu H P, Gao X F, Wu M, Zhu Y, Xiong R W, Ye S J. The efficiency and risk to groundwater of constructed wetland system for domestic sewage treatment-a case study in Xiantao, China. Journal of Cleaner Production, 2020, 123384.

[ 4 ] Rahman M M, Jiang Y, Irvine K. Assessing wetland services for improved development decision-making: a case study of mangroves in coastal Bangladesh. Wetlands Ecology and Management, 2018, 26(4): 563-580.

[ 5 ] Junk W J, An S Q, Finlayson C M, Gopal B, Květ J, Mitchell S A, Mitsch W J, Robarts R D. Current state of knowledge regarding the world's wetlands and their future under global climate change: a synthesis. Aquatic Sciences, 2013, 75(1): 151-167.

[ 6 ] Hu S J, Niu Z G, Chen Y F, Li L F, Zhang H Y. Global wetlands: potential distribution, wetland loss, and status. Science of the Total Environment, 2017, 586: 319-327.

[ 7 ] Tian B, Zhou Y X, Thom R M, Diefenderfer H L, Yuan Q. Detecting wetland changes in Shanghai, China using FORMOSAT and Landsat TM imagery. Journal of Hydrology, 2015, 529: 1-10.

[ 8 ] Wu M X, Li C W, Du J, He P M, Zhong S C, Wu P L, Lu H D, Fang S B. Quantifying the dynamics and driving forces of the coastal wetland landscape of the Yangtze River Estuary since the 1960s. Regional Studies in Marine Science, 2019, 32: 100854.

[ 9 ] Sun N, Zhu W N, Cheng Q. GF-1 and Landsat observed a 40-year wetland spatiotemporal variation and its coupled environmental factors in Yangtze River estuary. Estuarine, Coastal and Shelf Science, 2018, 207: 30-39.

[10] Lin W P, Cen J W, Xu D, Du S Q, Gao J. Wetland landscape pattern changes over a period of rapid development (1985-2015) in the ZhouShan Islands of Zhejiang province, China. Estuarine, Coastal and Shelf Science, 2018, 213: 148-159.

[11] Gan X J, Cai Y T, Choi C, Ma Z J, Chen J K, Li B. Potential impacts of invasive Spartina alterniflora on spring bird communities at Chongming Dongtan, a Chinese wetland of international importance. Estuarine, Coastal and Shelf Science, 2009, 83(2): 211-218.

[12] McKinney R A, Raposa K B, Cournoyer R M. Wetlands as habitat in urbanizing landscapes: Patterns of bird abundance and occupancy. Landscape and Urban Planning, 2011, 100(1/2): 144-152.

[13] Lv W W, Zhou W Z, Zhao Y L. Effect of freshwater inflow on self-restoration of macrobenthic diversity in seaward intertidal wetlands influenced by reclamation projects in the Yangtze estuary, China. Marine Pollution Bulletin, 2019, 138: 177-186.

[14] Zhang Y Z, Chen R S, Wang Y. Tendency of land reclamation in coastal areas of Shanghai from 1998 to 2015. Land Use Policy, 2020, 91: 104370 .

[15] Wang H, Ge Z M, Yuan L, Zhang L Q. Evaluation of the combined threat from sea-level rise and sedimentation reduction to the coastal wetlands in the Yangtze Estuary, China. Ecological Engineering, 2014, 71: 346-354.

[16] Cui L F, Ge Z M, Yuan L, Zhang L Q. Vulnerability assessment of the coastal wetlands in the Yangtze Estuary, China to sea-level rise. Estuarine, Coastal and Shelf Science, 2015, 156: 42-51.

[17] Zhong Q C, Wang K Y, Nie M, Zhang G L, Zhang W W, Zhu Y, Fu Y, Zhang Q, Gao Y N. Responses of wetland soil carbon and nutrient pools and microbial activities after 7 years of experimental warming in the Yangtze Estuary. Ecological Engineering, 2019, 136: 68-78.

[18] Ma L B, Bo J, Li X Y, Fang F, Cheng W J. Identifying key landscape pattern indices influencing the ecological security of inland river basin: The middle and lower reaches of Shule River Basin as an example. Science of the Total Environment, 2019, 674: 424-438.

[19] Zhang F, Zhan J Y, Li Z H, Jia S Q, Chen S J. Impacts of urban transformation on water footprint and sustainable energy in Shanghai, China. Journal of Cleaner Production, 2018, 190: 847-853.

[20] Kangalawe R Y M, Liwenga E T. Livelihoods in the wetlands of Kilombero Valley in Tanzania: opportunities and challenges to integrated water resource management. Physics and Chemistry of the Earth, Parts A/B/C, 2005, 30(11/16) : 968-975.

[21] Schwarz N. Urban form revisited-Selecting indicators for characterising European cities. Landscape and Urban Planning, 2010, 96(1) : 29-47.

[22] Li J X, Li C, Zhu F G, Song C H, Wu J G. Spatiotemporal pattern of urbanization in Shanghai, China between 1989 and 2005 . Landscape Ecology, 2013, 28(8): 1545-1565.

[23] Wu W T, Yang Z Q, Tian B, Huang Y, Zhou Y X, Zhang T. Impacts of coastal reclamation on wetlands: loss, resilience, and sustainable management. Estuarine, Coastal and Shelf Science, 2018, 210: 153-161.

[24] Tang Q Y, Zhang C X. Data Processing System (DPS) software with experimental design, statistical analysis and data mining developed for use in entomological research. Insect Science, 2013, 20(2): 254-260.

[25] Zhang Y, Zhang X. Grey correlation analysis between strength of slag cement and particle fractions of slag powder. Cement and Concrete Composites, 2007, 29(6): 498-504.

[26] 李倩, 梁宗锁, 董娟娥, 付亮亮, 蒋传中. 丹参品质与主导气候因子的灰色关联度分析. 生态学报, 2010, 30(10): 2569-2575.

[27］胡予红, 周心权, 刘毅. 基于灰色关联度分析的我国煤炭消费影响因素分析. 中国煤炭, 2009(04): 17-19.

[28] Liu Y L, Zhang X H, Kong X S, Wang R, Chen L. Identifying the relationship between urban land expansion and human activities in the Yangtze River Economic Belt, China. Applied Geography, 2018, 94: 163-177.

[29] Wang Z Y, Li Y T, He Y P. Sediment budget of the Yangtze River. Water Resources Research, 2007, 43(4) : W04401.

[30］史利江. 基于遥感和 GIS 的上海土地利用变化与土壤碳库研究 $[\mathrm{D}]$. 上海. 华东师范大学, 2009.

[31］岳书平, 张树文, 间业超. 吉林西部沼泽湿地景观变化及其驱动机制分析. 中国环境科学, 2008, 28(2): 163-167.

[32] 陈克林. 《拉姆萨尔公约》一一湿地公约》介绍. 生物多样性, 1995, 03(2): 119-121. 